\title{
Authoritarian Modernization in Russia. Ideas, Institutions, and Policies
}

\author{
Vladimir Gel'man (red.) \\ New York: Routledge 2017 \\ 214 sider. ISBN 9781472465412
}

\section{Omtalt av Mette Skak [PhD, lektor i statskundskab, Aarhus Universitet]}

Der er tale om en antologi, som er en udløber af det finske forskningsprojekt Choices of Russian Modernization med hjemsted på Aleksanteri-instituttet i Helsinki. Derfor er der et stort kontingent finske bidragydere, men bogens store værdi ligger især i de russiske forskeres bidrag, herunder Vladimir Gel'mans egne som redaktør og medforfatter. Denne anmelder holder meget af Gel'mans sociologiske diagnoser af Ruslands problemer med politisk og økonomisk udvikling, og han skuffer ikke her. Men endnu mere vil jeg fremhæve Andrey Zaostrovtsevs informative og deprimerende, men vigtige kapitel; det vender jeg tilbage til.

Det overordnede emne - Ruslands politiske økonomi - lanceres her som et bidrag til forskningen i modernisering, det vil sige et empirisk dybdestudie med afsæt i nøglebegrebet autoritær modernisering. Det bestemmes af Gel'man i indledningen som snævert tekniske politiske indgreb, der sigter mod at opnå høj socio-økonomisk udvikling gennem hurtig økonomisk vækst. Det snævre ligger $i$, at autoritære regimer med vilje styrer uden om liberale politiske reformer og heller ikke kerer sig om retsstaten. Alligevel er det blevet en populær opskrift på for økonomisk fremgang, idet tilgangen jo repræsenteres af Kina, det ubestridelige asiatiske vækstmirakel.

Men Gel'man understreger med henvisning til den politologiske sagkundskab, at det nærmest er undtagelsen, at autoritære moderniseringer lykkes. Bogens argument for at kaste sig over Rusland er således, at vi kan lære af Ruslands mislykkede modernisering. For det antydes med henvisning til den russiske analytiker Alena Ledeneva, at Rusland reelt er havnet $\mathrm{i}$ en moderniseringsfælde. Lige her bliver Gel'man desværre for indforstået og tager det for givet, at læseren er fortrolig med hendes argument. I et interview (Ledeneva 2013) har hun udtalt, at fraværet af institutioner til fordel for en uformel, personbåren magtstruktur af netværk - det amorfe sistema, som Putin anser for at omgive sig selv og alle andre i Rusland - udgør den konkrete moderniseringsfælde, som Rusland er fanget i.

^Kontaktinformasjon: Mette Skak 
Gel'man forklarer miseren med Ruslands særlige autoritære variant, hvad styreformen angår, nemlig det elektorale autoritære regime. Den hybrid kombinerer det værste ved både demokrati og diktatur. De tilbagevendende valg til Dumaen og præsidentvalgene forhindrer ledelsen i Kreml' i at tænke langsigtet og træffe strategiske beslutninger. Et aktuelt eksempel er den hårdt tiltrængte pensionsreform, som nu omsider - i ly af hurlumhejet omkring VM i fodbold - om ikke andet så delvis gennemføres trods protester. Samtidig betoner han, hvad angår idégrundlaget, at den russiske elite vitterlig identificerer sig med den autoritære tilgang, fordi den er "besat af statushævdelse", eller som han citerer en Putin-rådgiver for: »Putin became the creator of the 'Russian miracle' (...) despite expectations that Russia would leave the global stage and turn into something like Indonesia» (s.8), hvortil kom hævntørst over for Vesten. Senere fælder Gel'man dom over elitens tilgang som irrelevant, når det drejer sig om at modernisere.

Ud over idégrundlaget handler bogen om institutioner (fraværet af) og politikker. Gel'man er medforfatter på et spændende kapitel, der i bedste Turgenjev-stil ser på fædre og sønner i de nulevende generationer af russiske reformpolitikere. Generationssociologi er Gel'mans varemærke og en af grundene til min begejstring for ham. Han antyder, at håbet for en bedre fremtid ligger i skiftet mellem generationerne og den biologiske udløbsdata for Putin og hans hold, og at vi hen ad vejen vil se en ny og anderledes dynamik i Rusland. Markku Kangaspuro leverer en fængende analyse af dilemmaet mellem kravet om en stærk stat i Rusland og behovet for modernisering. Han understreger de mange selvmodsigelser i den russiske befolknings holdninger, for på den ene side jublede den over annekteringen af Krim som noget, der på ny gjorde Rusland til supermagt, og på den anden side er det velfærdsgoder som høj levestandard, ikke militær slagkraft, som russerne lægger i det at være en supermagt. I det lys er vi i Norden godt med! Bortset fra det er Kangaspuros nedslående konklusion, at russerne er ligeglade med modernisering i bred politisk forstand, eftersom der ikke er noget pres fra neden for noget sådant.

Som antydet er Zaostrovtsevs kapitel om institutionelt forfald alle pengene værd. Det er spækket med komparative data, som udstiller, at Rusland vitterlig befinder sig $i$ en blindgyde sammenlignet med postsovjetiske stater som Ukraine og Kasakhstan. Det er i Rusland, at man finder den mest kyniske holdning til værdien af demokrati på niveau med lande som Den Centralafrikanske Republik og Afghanistan, der jo ikke just er skoleeksempler på oplysning. Derudover kobler han den folkelige opbakning til autokratiet - Putins enevælde - sammen med aggressive imperialistiske holdninger $\mathrm{i}$ brede lag $\mathrm{i}$ den russiske befolkning. Institutioner som ejendomsretten og retsstaten er følgelig notorisk svage i Rusland, idet Kreml uhindret kan praktisere "state racketeering", som han skriver - det vil sige statens mafiøse virksomhedsran. Det får til gengæld de mest entreprenante og innovative russere til at udvandre, ligesom de udenlandske investorer trækker sig. Zaostrovtsev slutter med at citere Ledeneva for statens kvælertag på markedet og følger op med diagnoser som "predatory state» og "parasitic worm". 


\section{6 | METTE SKAK}

Der er knap så megen slagkraft i de øvrige kapitler, men de er alle nyttige, faktuelle analyser af værdi i undervisningssammenhænge på universitetsniveau. Et af de bedre er forfattet af Jussi Lassila og omhandler et pudsigt udslag af topstyringen af det politiske liv i Rusland, nemlig oprettelsen af Den Russiske Folkefront. Den tjener som lynafleder ved at tage oppositionens mærkesager op. Lassila konkluderer, at det konforme civilsamfund, som Folkefronten udgør, ikke for alvor løser problemerne for Kreml, og det gør ham til en forsigtig optimist. Jukka Pietiläinen kortlægger moderniseringsdiskursen i Rusland. Det undrer mig, at han ikke gør det klart, at slagordet "modernizatsia» i den daværende præsident Medvedevs mund mest drejede sig om at ændre eksportstrukturen, så Rusland kunne tjene penge på andet end olie og gas. Her styrede han klogeligt uden om den økonomiske fagterm diversificering som alt for fremmedgørende. Ergo en snævert teknisk reform, der nøje svarer til, hvad vi skal lægge i bogens kernebegreb den autoritære modernisering. Spørgsmålet er imidlertid, om en modernisering på autoritære præmisser længere er Putins "grand strategy«? Andre forfattere påviser nemlig et skred i retning af regimesikkerhed som den egentlige mærkesag.

\section{Referanser}

Ledeneva, Alena (2013) »Interview: How Russia's 'Sistema' Leads To The Modernization Trap«. RadioFree Europe/RadioLiberty - Russia, 1. april. 